\title{
招待講演 2
}

\section{魚油による生活習慣病予防機序}

国立健康・栄養研究所江崎治

魚油には、血中中性脂肪值低下作用を低下させる効果が有り、その主成分である EPA は虚血性 心疾患や高中性脂肪血症患者の治療薬としても用いられている。魚油の血中中性脂肪值低下作用 は肝茂での脂肪酸亚化の六進と中性脂肪合成能の低下によるものと考えられる。脂肪酸酸化の 元進は PPAR $\alpha$ 活性化により、中性脂肪合成能の低下は SREBP-1c の完成型の量の減少による。 又、マウスでは高紅花食では肥満を生じるが、高魚油食では肥満を生じない。本研究では肝葴と 脂肪組織での遗伝子発現のバターンを調ベると共に、主要な遗伝子の発現レベルを魚油の投与量 を変えて調べ、魚油による生活翼慣病予防機序を推定した。

8 週秢の C57BL/6 マウスを高炭水化物食群、脂肪エネルギ一比 $60 \%$ 高紅花油食群と高魚油 食群の 3 群に分けた。6ヶ月飼育㖟、肝䁍及び脂肪組織より mRNA を抽出し遗伝子発現をジーン チップ Murine 6.5K を用い解析した。肝葴では高紅花油食群と比較して高魚油食群では PPAR aにより制御される遗伝子(FATP, Cyp4a-10, long chain fatty ACS, UCP2)の発現が増加した。 さらに immunoglobulin 関連遗伝子や抗酸化関連遺伝子(各種 glutathione transferase, Mn$\mathrm{SOD})$ 発現も増扣した。一方、高紅花油食群上比較し高魚油食群で脂質代謝関連遗伝子(SREBP1c, SCD-1, ATP citrate lyase, FAS, squalene epoxidase, farnesyl pyrophosphate synthetase, LDL receptor)やステロイド系の内因性 PPAR $\alpha$ activator を合成する醳素 17-hydroxykase / C-17,20-lyase や sulfotransferase の発現が著明に低下した。又、魚油の投与量を 10-60\%に 変えて主要な遗伝子の発現レベルを調べたところ、投与量に比例してP P A R $\alpha$ タ一ゲット遺伝 子の発現量が增加するのに対し、有意な SREBP-1c mRNAの減少は 30\%以上から認められ、FAS， $\mathrm{ACC}, \mathrm{SCD} 1, \mathrm{HMG}-\mathrm{COA} の \mathrm{mRNA} の$ 20-50\%の低下が 10\%以下の少ない魚油投与量でも認めら れた。脂肪組緎については、hormone sensitive lipase (HSL)の軽度の発現増加が認められたの みで、脂肪合成に関与する酵素 (ATP citrate lyase, FAS, Glycerol-3-phosphate acyltransferase) の発現が增加し、B酸化に関与する酵素群はほとんど変化しなかった。

以上のように魚油の椇取による抗肥満／抗中性脂肪作用は主として肝䁍での脂肪分解促進、合 成抑制により生じ、更に、これらの主要な遺伝子の発現レベルは日常の魚油の攝取量の範囲でも 変化した。又、肝䁍における $\beta$ 酸化の方進に对し、抗酸化関連遗伝子の発現を增加させ、ROS 産 生遗伝子や内因性 PPAR $\alpha$ activator 合成醉素の発現を減少させ、生体を防御していることが示 唆された。 